\title{
Reflections
}

\section{Scalp expansion: Surgical considerations and possible future directions}

\section{Edoardo Raposio 1,2}

${ }^{1}$ Department of Medicine and Surgery, University of Parma, ${ }^{2}$ Department of Surgical Specialties Cutaneous, Mininvasive, Regenerative and Plastic Surgery Unit, Parma University Hospital, Parma, Italy

Address for correspondence: Prof. Edoardo Raposio, Department of Medicine and Surgery, University of Parma, Via Gramsci 14, 43126, Parma, Italy.

E-mail: edoardo.raposio@unipr.it

\section{ABSTRACT}

Introduction: Repairing large scalp defects has always been a difficult task for plastic surgeons. This is because the requirements of such procedures are two-fold: sufficient soft-tissue coverage is required, and to obtain a satisfactory aesthetic outcome, a sufficient number of covering hairs should be ideally provided. Materials and Methods: Based on the author's experience in this repair technique over a 20-year period, this article presents some technical details of scalp expansion, surgical refinements and possible directions for further technical advancement. Results: Data and details on relevant scalp anatomy, expander choice, expander placement, subgaleal undermining, galeotomies and acute scalp expansion are provided. Conclusions: The author hopes that the above-mentioned details may be of some utility in the complex field of scalp expansion.

\section{KEY WORDS}

Scalp reconstruction; scalp surgery; tissue expansion

\section{INTRODUCTION}



issue expansion has been described extensively as a useful technique for covering large scalp defects $^{[1-4]}$ [Figure 1]. Tissue expansion is ideal for scalp defects because the skull acts as a rigid base for the expander and the overlying scalp is thick; this helps reduce the risk of thinning and extrusion of the implant. Moreover, due to the excellent vascularisation in the region, the risk of infection is low. In addition,

\begin{tabular}{|l|l|}
\hline \multicolumn{2}{|c|}{ Access this article online } \\
\hline Quick Response Code: & Website: \\
\hline & www.ijps.org \\
\cline { 2 - 2 } & Dol: \\
\hline
\end{tabular}

the biomechanical properties of scalp flaps are rather peculiar, and the amount of hair follicles available is limited. In the present paper, the author analysed some peculiar technical details of scalp expansion.

\section{METHODS AND RESULTS}

The following aspects have some importance in the field of scalp expansion:

This is an open access journal, and articles are distributed under the terms of the Creative Commons Attribution-NonCommercial-ShareAlike 4.0 License, which allows others to remix, tweak, and build upon the work non-commercially, as long as appropriate credit is given and the new creations are licensed under the identical terms.

For reprints contact: reprints@medknow.com

How to cite this article: Raposio E. Scalp expansion: Surgical considerations and possible future directions. Indian J Plast Surg 2018;51:84-8. 


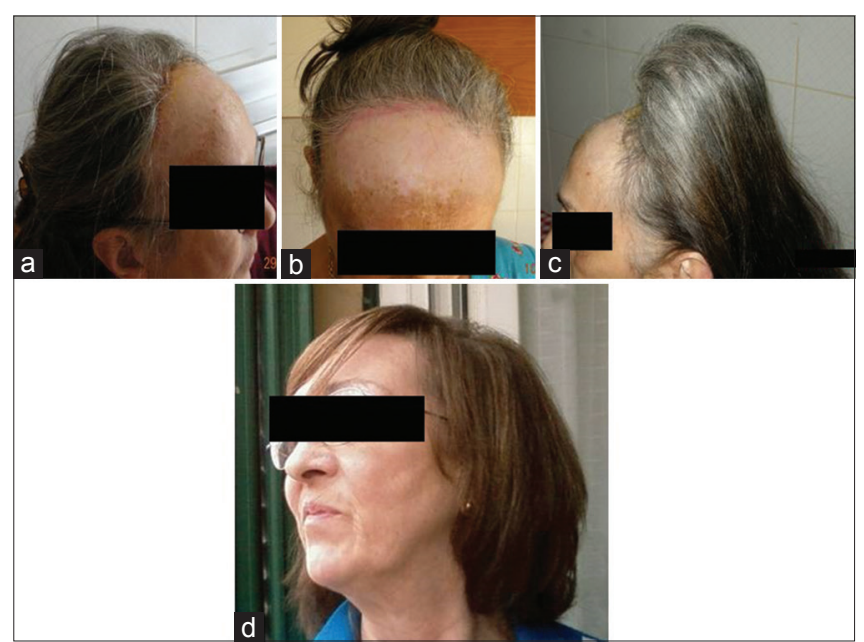

Figure 1: Lateral (a) and frontal (b) view of a 52-year-old patient with post-burn cicatricial alopecia of the frontal scalp. (c) After subgaleal rectangular expander placement and 4 months of expansion. (d) Final result

\section{Scalp anatomy in relation to tissue expansion}

Knowledge of scalp anatomy is essential for planning scalp expansion. From the surgical point of view, the scalp comprises five $e^{[5]}$ as follows: the epidermis, dermis, subcutaneous tissue, the layer containing the major vessels and the galea aponeurotica [Figure 2]. In the currently used approach, an expander is placed between the galea aponeurotica and the pericranium. This is because all the major vessels of the scalp (the supratrochlear, supraorbital, superficial temporal, posterior auricular and occipital arteries) run only over the galeal surface, which makes supragaleal undermining difficult. Conversely, the subgaleal layer is almost avascular and very easy to undermine. Theoretically, if the major vessels are directly isolated, an expander could be placed above the galea (potentially augmenting the elasticity of the flap to be expanded), but the feasibility of this approach has never been tested, and it might be time-consuming.

\section{Expander choice}

In general, the shape of the tissue expander base affects the amount of tissue gain. For example, expanders with a round base, a crescentic base and a rectangular base provide a tissue gain of $25 \%, 32 \%$ and $38 \%$, respectively. ${ }^{[6]}$ With the exception of peculiar cases, a rectangular expander can theoretically be used in all procedures. However, no studies have been performed to evaluate if and how the peculiar, round-shaped anatomy of the scalp might influence the effectiveness of a rectangular expander. There is also the possibility that a crescent-shaped expander may be a better fit above the cranium than a rectangular one: This needs to be explored in future.

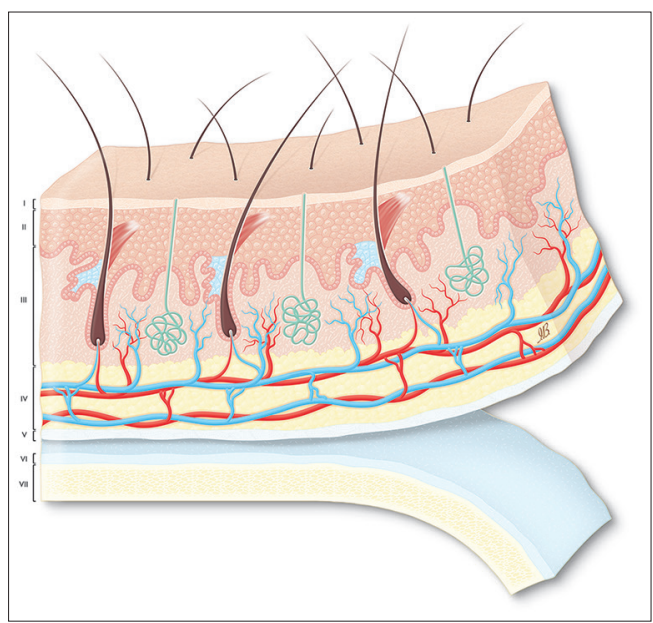

Figure 2: Surgically relevant scalp layers: (i) epidermis, (II) dermis, (III) subcutaneous tissue, (IV) layer containing the major vessels, (v) galea aponeurotica. (VI) Pericranium, (VII) cranium

\section{Expander placement}

As stated previously, a scalp expander should always be positioned in the subgaleal layer. The expander is usually placed close to the defects to be reconstructed, and it is advisable to insert it parallel to the longest side of the lesion to be removed. For placing the expander, a small incision in the right (radial to the expander) direction permits the immediate post-operative start of the expansion and avoids the delay of several weeks required for ensuring that the incision has sufficient tensile strength. The first filling of the expander is usually performed in conjunction with its placement $(10 \%$ of the nominal expander volume). At 1-2 weeks after the procedure, one to two weekly filling sessions $(10 \%-20 \%$ of the nominal expander volume per each session) are initiated, and the expander is usually sufficiently expanded within $6-8$ weeks. ${ }^{[7]}$ A relevant point that needs to be addressed is the projection of the expander. The projection is the most important factor with regard to producing as much expanded tissue as possible. This fundamental concept can easily be extrapolated, for example, by using the same amount of saline in equal-volume expanders, but displacing the expanders in such a way that different projection rates are obtained [Figures 3 and 4]. Although the expander and fill are the same, the tissue gain achieved with the higher projection is quadruplicated.

\section{Subgaleal undermining}

Although the greatest amount of scalp mobility is observed in the parietal regions, where the temporoparietal fascia slides over the deep temporal fascia, the entire scalp benefits from increased undermining during placement of an expanded scalp flap. Indeed, the tensiometric 


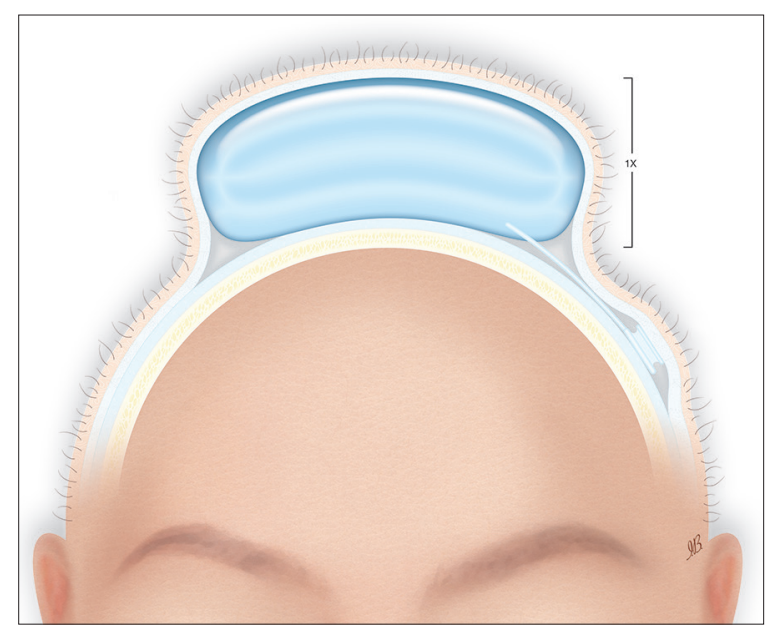

Figure 3: A rectangular tissue expander, with the base placed horizontally (conventionally)

properties of the scalp are significantly altered with increased subgaleal undermining. ${ }^{[8-9]}$ The greater the undermining, the lesser is the closing tension required. For example, in the case of a midline transverse scalp defect of $15 \mathrm{~mm}, 1,5$ and $15 \mathrm{~cm}$ of undermining on both sides requires a tension load of 4500, 460 and $410 \mathrm{gf}$, respectively [Figure 5]. Tension load is achieved by connecting the scalp flap to a force-distributing dynamometer (FD102/FD111, Borletti, Florence, Italy) and a force transducer (D200, Maywood Instruments Ltd., Hampshire, UK). The $5 \mathrm{~cm}$ undermining reduces the tension by $10.22 \%$ while the $15 \mathrm{~cm}$ undermining reduces it by $9.11 \%$ (as measured for a $15 \mathrm{~mm}$ advancement on each side). These values represent a mean gain of 61.9 and $6.05 \mathrm{~g} / \mathrm{mm}$ in the plasticity (considered as the inverse of stiffness) of the described scalp flaps for each unit increment in the amount of undermining, being the stiffness biomechanically defined by the slope of the middle portion of the stress-strain curve, calculated by dividing the tension load by the advancement of the flap. It would be interesting to perform a study to examine the usefulness of routinely undermining the whole scalp as a rational approach to significantly diminishing the tension on wound margins when expanding a scalp flap. It would be noteworthy to investigate whether this approach might lead to an increase in the rate of post-operative complications (namely, sieroma, haematoma and infections) as a direct consequence of the creation of larger subgaleal pockets.

\section{Galeotomies}

Plastic surgeons are well aware of the usefulness of relaxing incisions of the galea aponeurotica for transposing a scalp flap. Although care should be taken to avoid

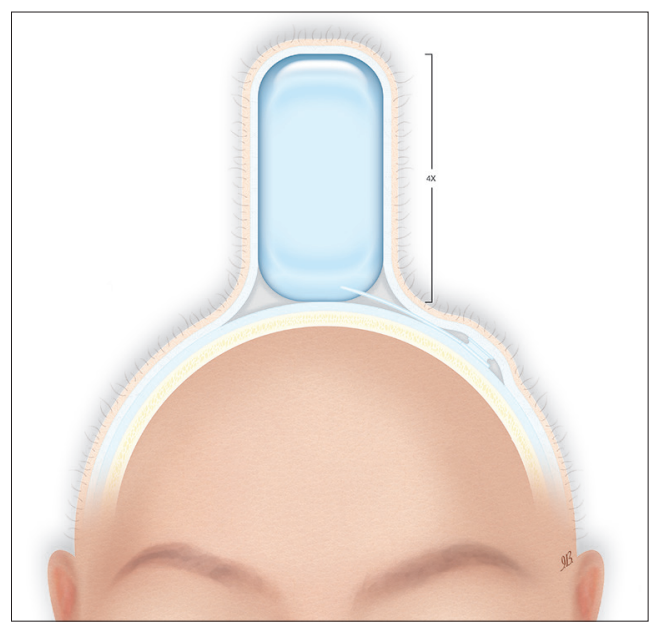

Figure 4: Same expander as in Figure 3, with the base placed vertically. The projection (tissue gain) is increased about four-fold

injury to the overlying vascular network, galea-relaxing incisions can be used to help improve scalp mobility after expansion. Galeal incisions reduce scalp closing tension by $40 \%$ and provide $1.67 \mathrm{~mm}$ of tissue gain for each galeotomy. ${ }^{[10-11]}$ For example, to close a scalp defect of $20 \mathrm{~mm}$, a tension load of 4.1 and $1.9 \mathrm{kgf}$ is required before and after the relaxing incision, respectively, of the galea aponeurotica [Figure 6]. These data are indicative of a mean gain of $5.53 \mathrm{~g} / \mathrm{mm}$ per galeotomy in the plasticity (considered as the inverse of stiffness) of an expanded scalp flap. The drawbacks correlated to the use of galeotomies may be an increased risk of intra-operative bleeding and post-operative haematoma. The risk of hampering the viability of the transposed scalp flaps is also prominent. The above-reported data are indicative of a positive cost/benefit ratio with their extensive use after scalp expansion. At present, the effect of galeotomies before scalp expansion (i.e., at the time of expander placement) still needs to be clarified.

\section{Acute (intra-operative) scalp expansion}

Since its introduction by Sasaki ${ }^{[12]}$ in 1988, several authors $^{[13-16]}$ have reported successful soft-tissue reconstruction using intra-operative tissue expansion. Unfortunately, the tensiometric properties of a conventional scalp flap are not altered by acute expansion. Indeed, the biomechanical benefits provided by acute scalp expansion are not different from those obtained by simple subgaleal undermining ${ }^{[17]}$ [Figure 7]. The relative inelasticity of the scalp seems to oppose the principle (acute mechanical creep) on which intra-operative tissue expansion is based. Mainly owing to the presence of the galea aponeurotica, the mean stiffness of a scalp flap is approximately three to four 


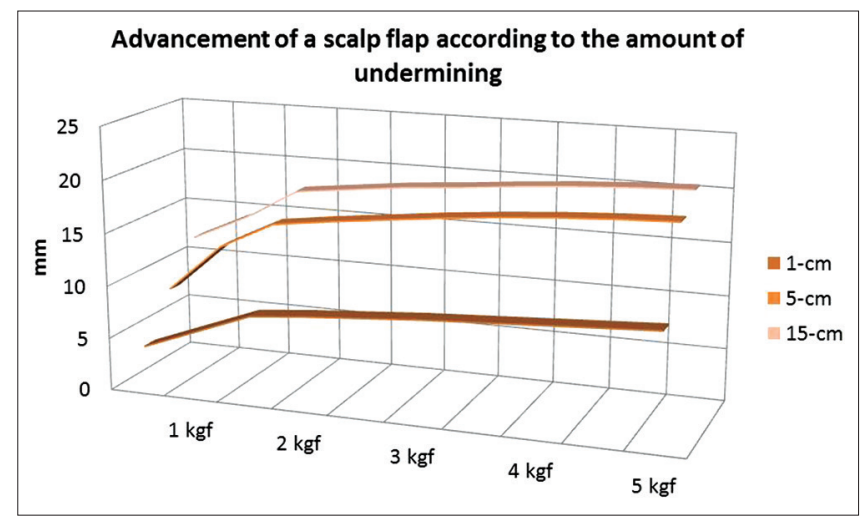

Figure 5: Advancement of a scalp flap after 1,5 or $15 \mathrm{~cm}$ of undermining The mean stiffness of the scalp flaps is highlighted by the graded amount of load (kgf)

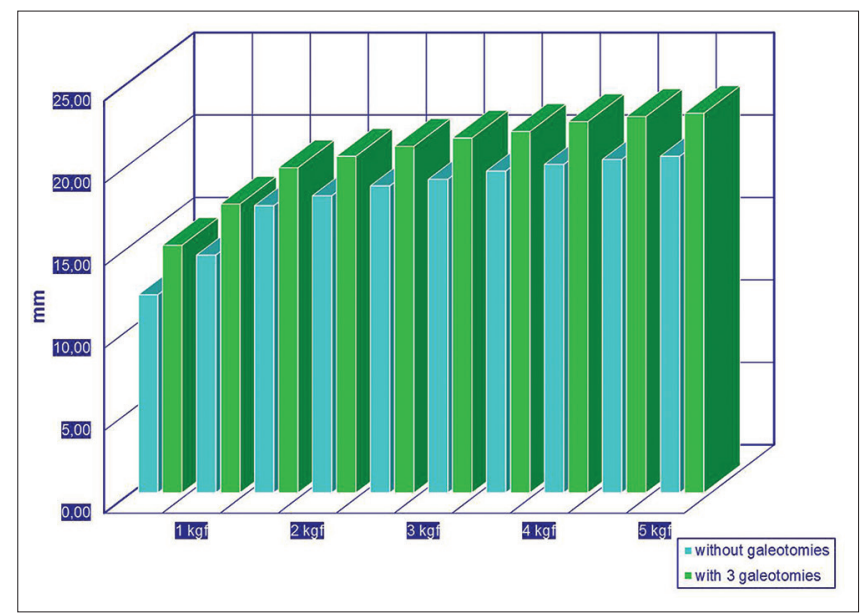

Figure 6: Elongation of a rectangular scalp flap with or without n. 3 galeotomies, performed parallel to the long axis of the flap. The initial galeotomy was placed $2 \mathrm{~cm}$ from the flap edge, whereas the second and third galeotomies were placed $1 \mathrm{~cm}$ lateral from the initial and the second galeotomy respectively. The stretching of the flaps is reported after a stepwise loading stress.

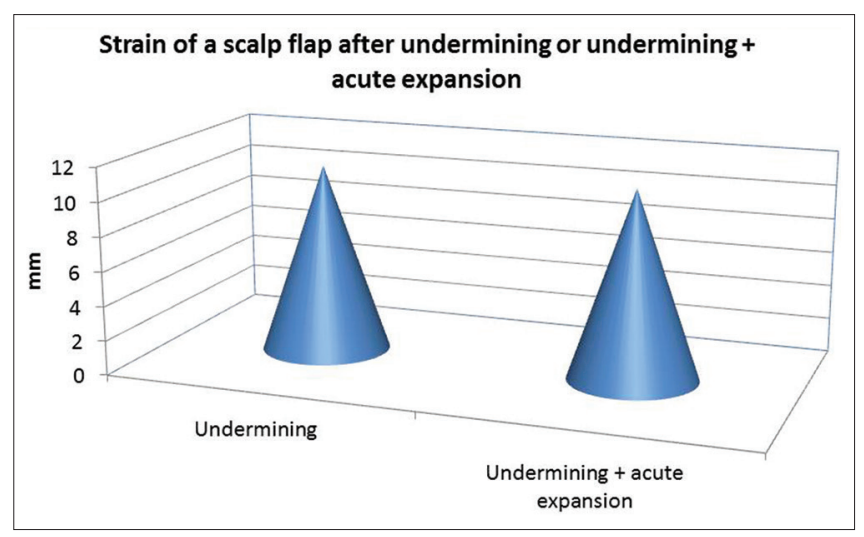

Figure 7: Mean strain (in $\mathrm{mm}$ ) in undermined and acutely expanded scalp flaps as measured with a stress (tension-load) of $1.5 \mathrm{kgf}$. There is no difference between the two groups of flaps

times the mean stiffness of a cutaneous flap elevated on either the abdomen or the dorsum of the hand. ${ }^{[18-19]}$ Acute scalp expansion is ineffective probably because the inelasticity of the galea aponeurotica does not allow expansion of the elastic overlying scalp skin through the effect of mechanical creep. A clinical study evaluating if and to what extent galeotomies might affect the acute expansion of a scalp flap would be useful since, at present, no data are available to support this hypothesis.

\section{CONCLUSIONS}

The scalp is an excellent source of expanded tissue, but it has several special features that should be noted for successful expansion. Providing some details on anatomy, expander choice, expander placement, subgaleal undermining, galeotomies, and acute scalp expansion, the author hope to have underlined some peculiar characteristics of this valuable technique.

\section{Declaration of patient consent}

The authors certify that they have obtained all appropriate patient consent forms. In the form the patient(s) has/have given his/her/their consent for his/her/their images and other clinical information to be reported in the journal. The patients understand that their names and initials will not be published and due efforts will be made to conceal their identity, but anonymity cannot be guaranteed.

\section{Financial support and sponsorship: None} Nil.

\section{Conflicts of interest}

There are no conflicts of interest.

\section{REFERENCES}

1. Merlino G, Carlucci S. Role of systematic scalp expansion before cranioplasty in patients with craniectomy defects. J Craniomaxillofac Surg 2015;43:1416-21.

2. Desai SC, Sand JP, Sharon JD, Branham G, Nussenbaum B. Scalp reconstruction: An algorithmic approach and systematic review. JAMA Facial Plast Surg 2015;17:56-66.

3. Maillet-Declerck M, Calibre C, Herbaux B, Duquennoy-Martinot V. Long-term results in scalp tissue expansion in children. Eur $J$ Pediatr Surg 2012;22:269-73.

4. Guzey S, Alhan D, Şahin I, Aykan A, Eski M, Nişancı M, et al. Our experiences on the reconstruction of lateral scalp burn alopecia with tissue expanders. Burns 2015;41:631-7.

5. Raposio E, Caruana G. Scalp surgery: Quantitative analysis of follicular unit growth. Plast Reconstr Surg Glob Open 2015;3:e539.

6. Nordström RE, editor. Scalp. In: Tissue Expansion. Boston (MA): Butterworth-Heinemann; 1996. p. 107-23.

7. Nordström RE, Raposio E, Fan J. Geometric planning. In: Nordstrom RE, editor. Tissue Expansion. Boston (MA): Butterworth-Heinemann; 1996. p. 13-7. 
8. Raposio E, Nordström RE, Santi PL. Undermining of the scalp: Quantitative effects. Plast Reconstr Surg 1998;101:1218-22.

9. Raposio E, Nordström RE. Tension and flap advancement in the human scalp. Ann Plast Surg 1997;39:20-3.

10. Raposio E, Santi $P$, Nordström RE. Effects of galeotomies on scalp flaps. Ann Plast Surg 1998;41:17-21.

11. Nordström RE, Greco M, Raposio E. The 'Nordstrom suture' to enhance scalp reductions. Plast Reconstr Surg 2001;107:577-82.

12. Sasaki GH. Intraoperative expansion as an immediate reconstructive technique. Facial Plast Surg 1988;5:362-78.

13. Raposio E, Cella A, Panarese P, Nordström RE, Santi P. Anchoring galeal flaps for scalp reduction procedures. Plast Reconstr Surg 1998;102:2454-8.

14. Raposio E, Nordström RE, Santi P. Aesthetic reconstruction of the vertex area of the scalp. Case report. Scand J Plast Reconstr Surg Hand Surg 1998;32:339-41.

15. Raposio E, Santi PL, Nordström RE. Serial scalp reductions: A biomechanical approach. Dermatol Surg 1999;25:210-4.

16. Nordström RE, Raposio E. Scalp extension - A quantitative study. Dermatol Surg 1999;25:30-3.

17. Raposio E, Cella A, Barabino P, Santi P. Ineffectiveness of acute scalp expansion. Plast Reconstr Surg 1999;103:1645-9.

18. Raposio E, Adami M, Capello C, Ferrando G, Molinari R, Renzi M, et al. Intraoperative expansion of scalp flaps. Quantitative assessment. Minerva Chir 2000;55:629-34.

19. Raposio E, Cella A, Panarese P, Caregnato P, Gualdi A, Santi PL, et al. Quantitative benefits provided by acute tissue expansion: A biomechanical study in human cadavers. $\mathrm{Br} \mathrm{J}$ Plast Surg 2000;53:220-4. 